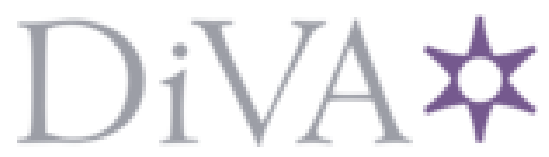

http://www.diva-portal.org

This is the published version of a paper published in European Educational Research Journal (online).

Citation for the original published paper (version of record):

Lindberg, L. (2002)

Is "Pedagogik" as an Academic Discipline in Sweden just a Phenomenon for the Twentieth

Century?: The Effects of Recent Education Reform..

European Educational Research Journal (online), 1(1): 65-82

http://dx.doi.org/10.2304/eerj.2002.1.1.13

Access to the published version may require subscription.

N.B. When citing this work, cite the original published paper.

Permanent link to this version:

http://urn.kb.se/resolve?urn=urn:nbn:se:Inu:diva-37632 


\title{
Is 'Pedagogik' as an Academic Discipline in Sweden just a Phenomenon for the Twentieth Century? The Effects of Recent Education Reform
}

\author{
LEIF LINDBERG \\ Växjö University, Sweden
}

\begin{abstract}
In this article, the disciplinary transitions of Pedagogik in Sweden during the last century are examined. The material used includes written expert assessments, inaugural lectures, syllabuses, descriptions of teaching and research duties, governmental reports and research activities. Three different periods are detectable. From the first decade until the mid-century, an embryonic stage of psychometrics and intelligence testing could be observed. From mid-century up to the mid-1970s, a neo-behaviouristic paradigm was growing strong and dominated school research and a new teacher education was launched, supported with professorships in school research. From the mid-1970s up to the turn of the century, research was characterised by a variety of research perspectives and approaches. The conception of the discipline seems to be stable but under development. Parliamentarians searched for another knowledge base for teacher education than Pedagogik at the end of this period. There is evidence of Pedagogik moving towards an interdisciplinary approach, but there are also contradictory movements.
\end{abstract}

The focus here is on Pedagogik [1] as an academic discipline in Sweden during the last century, especially in connection with university reforms and changes in teacher education. When looking at changes of research interests and reform considerations during the last part of the century, it seems reasonable to ask in what direction the discipline is heading.

The Swedish Council for Research in the Humanities and Social Sciences' (HSFR) evaluation of educational research in Sweden (Rosengren $\&$ Öhngren, 1997) points out a number of different research foci, even though the evaluators also identify two different main streams: frame factor theory and phenomenography. Compared with the situation in the period 
1960s/1970s when a neo-behaviouristic paradigm dominated educational research in Sweden (Lindberg \& Lindberg, 1983, p. 217), is this a dramatic change? Ahlström \& Magnusson (1997) state that the discipline is already divided into subdisciplines, but they also maintain:

that research is actor directed, that is, it takes an interest in how practitioners as teachers, senior faculty administrators and so on think, reason, and act in their daily work compared with before when the focus was on system issues. (pp. 94-95; my translation)

These observations point towards a transition of the discipline in the direction of an interdisciplinary approach. However, it should be kept in mind that what is said above is about research.

Another and quite different angle, but still of great importance for the discipline, is the late 1990s committees on teacher education and their views of Pedagogik. It seems that these have an ambivalent attitude towards the discipline. Since Pedagogik in Sweden has had a role in teacher education during the twentieth century, a change of teacher education also has bearing on the discipline in different respects: one committee in particular was negative about Pedagogik (SOU [Official Reports of the Swedish Government], 1999:63).

The purpose of the project, with the same name as the title of this article, is to construct a picture of the discipline based on activities, which, taken together, constitute the discipline, and relate this picture to descriptions of earlier periods of the century. This article is an outline of such a picture. The project is, on the one hand, a continuation of my own previous studies of Pedagogik as an academic discipline with a focus on research (Lindberg $\&$ Lindberg, 1983) and inaugural speeches (Lindberg \& Berge, 1988). It is also an expansion of these in the sense that all activities by the name of Pedagogik are of interest when one tries to understand the transitions going on. These activities are seen as complementary, which means that there is no a priori given hierarchy among them. This position also means that I am doubtful about the possibility of constituting a discipline solely based on research activities (Lindberg, 1992). My reasons are: (i) the amount of research is too small and not homogeneous enough to constitute a content for the discipline. The mass of knowledge is simply too small, especially in the pre-war period; (ii) research with strong ties to national issues is too narrow and mixed up with the political issues of the day to offer a sufficiently stable base for a discipline; (iii) an academic discipline like Pedagogik does not solely answer to academic demands such as scholarly work with theory. An academic discipline is established for certain reasons and can therefore be said to be an answer to questions other than academic. The establishment of a professorship and the determination of its content become part of the solution of the issues that served as the legitimisation for the professorship. In other words, an ecological perspective could contribute to the understanding of a discipline's 
establishment, content, 'rise' and possible 'fall' (cf. Karnung, 2001, p. 258, and his analysis of the rise of qualitative educational research in the USA).

Understanding the ecology of a discipline is important. Some body or bodies have to give both resources and legitimate activities within a discipline (cf. Geiger, 1975). However, there also are activities within a discipline which, beyond research, can be of interest when studying, as here, disciplinary transitions. The disciplinary process is important. New university teachers meet and interact within an academic milieu. They get acquainted with conceptions of the field of study, attend seminars and lectures and, of course, they read books, articles, doctoral theses and so on (cf. Hofstetter \& Schneuwly, 2001, pp. 24-25).

The professionalisation process operates through a variety of channels that are open to researchers. The Higher Education Ordinance in Sweden requires that all compulsory readings and course content are listed for all courses. Other recorded activities include descriptions of teaching and research duties, criteria, inaugural lectures, and assessors' written reports on the applicants for professorships' contribution to the understanding of what is going on within the discipline. Table I summarises the materials used within a project of which this article is a first report. It distinguishes two types of research materials: talk about or statements on Pedagogik and work within Pedagogik. I look upon these two types of material as supplementary when trying to understand the dynamic processes that constitute the discipline of pedagogic in Sweden.

\begin{tabular}{llll}
\hline & $\begin{array}{l}\text { Activities } \\
\text { Research }\end{array}$ & Teaching & Determinations \\
\hline $\begin{array}{l}\text { Statements on } \\
\text { 'Pedagogik' }\end{array}$ & $\begin{array}{l}\text { Research plans } \\
\text { Research programmes } \\
\text { Commissions }\end{array}$ & $\begin{array}{l}\text { Educational descriptions } \\
\text { Syllabuses }\end{array}$ & $\begin{array}{l}\text { Descriptions of } \\
\text { teaching and } \\
\text { research duties }\end{array}$ \\
& & & $\begin{array}{l}\text { Written expert } \\
\text { assessments }\end{array}$ \\
& Inaugural lectures \\
'Pork within & $\begin{array}{l}\text { Research production } \\
\text { 'Pvaluations }\end{array}$ & $\begin{array}{l}\text { Required readings } \\
\text { (undergraduate and } \\
\text { doctoral levels) }\end{array}$ & Evaluations \\
\hline
\end{tabular}

Table I.

Some of the materials in the table are still being collected. For some materials the collection is completed but the analysis of these is not finished yet. Inaugural lectures, for example, have been collected and analysed from 1910 up to and including 1982 (Lindberg \& Berge, 1988). The remaining lectures during the century are still being collected. The written expert assessments of 
the applicants for professorships have to be commented upon due to the fact that they seem to be unique in analysis of this kind.

From 1876 up to 1999 , the processes of recruitment of professors in Sweden have been fairly similar. Central in the assessments of the applicants' qualifications have been (and still are) the written expert reports. The novelty in the 1876 Higher Education Ordinance, compared to older ones, was that experts (sakkunniga) should assess the qualifications of the applicants for a professorship. Before 1876, the qualifications of the applicants were assessed by the members of the faculty concerned and/or the university senate. In 1916, the procedures for appointing experts for the assessment of qualifications were changed. A university board could appoint three or four experts only after the other faculties in the country had been given the opportunity to put forward proposals of suitable experts. The faculties had to take these proposals seriously. This regulation is sometimes called 'inter academic cooperation', and made the recruitment procedure a national matter (Lindberg, 2000b).

There is a widespread consensus about the use of external experts in the assessment process. Several commissions during the century show this. On the other hand, one of the main issues for the commissions has been the lengthy process involved in the employment of professors. The first report from one of these commissions was published in 1922 and it contains an analysis of the employment of professors from 1606 up to the beginning of the century (SOU, 1922:17). The documents about the struggle for a professorship are public and thus they can be studied systematically. Normally these documents are very informative; sometimes they even contain a review of the origin of a professorship or an extensive discussion of the content of a professorship. A complete set of documents of all competitions from 1910 up to and including 1999 has been collected.

The presentation is in three sections:

Pedagogik Period One: 1901-50

Data based on inaugural speeches, written expert assessments completed with governmental documentation about each chair and the professors' research production. The redefinition of the chairs in the middle of the century marks the turn to the next part.

Pedagogik Period Two: 1950s-70

Data based on governmental reports, written expert assessments, governmental documentation about each chair, inaugural speeches and the total research production during the period.

Pedagogik Period Three: 1970s-2000

Teacher education is now transferred to the university sector. Data based on the university reforms, syllabuses and descriptions of teaching and research duties and parliamentary reports. 
I have used somewhat different material in the presentation of the periods. The reasons are as follows. First, the general question asked in this symposium has guided my choice. Second, as indicated earlier, some of the materials are under collection or are not yet fully analysed. These are just partly used. Third, some materials are not collected yet. In fact, analysed material for the last period is still missing. This means that the presentation of the last period is more sketchy and tentative compared with the two first periods. However, a more comprehensive analysis is in preparation.

\section{Pedagogik 1900-50}

Although the creation of the first chair dates back about 100 years, the first lectures on the science of upbringing at a Swedish university seem to have been given by a professor of philosophy (Daniel Boetius), at Uppsala University during the spring semester 1784. Between 1788 and 1792 he gave several series of lectures. These were printed under the title 'Primae Scientiae Educationis Lineae' and dealt with such issues as the aim of upbringing for individuals and society, how to carry out upbringing, different human faculties, and how society should assist the coming generation through upbringing and education (Boethio, 1788-1792).

The first professor, Bertil Hammer, held his inaugural lecture at Uppsala University on 8 October 1910. Between 1912 and 1937 three additional chairs were created at the University of Lund (1912), and the university colleges of Gothenburg (1919) and Stockholm (1937). The creation of these first chairs was determined mainly by the idea that the professors should take responsibility for the theoretical aspects of the pedagogical training of secondary school teachers and teachers at teacher training colleges (Lindberg \& Lindberg, 1983, p. 13). Thus, the creation of the first chairs was closely connected with the training of teachers. As far as the general orientation of early educational research is concerned, however, there was definitely a gap between this and the taught courses for becoming secondary school teachers. These courses were already prescribed in the national Degree Ordinance from 1907 in which the content was given: a course in psychology and history and theory of Pedagogik (Lindberg \& Lindberg, 1983, p. 15). The duration of the course was about half a semester. What was given to the first professors of teacher education were teaching duties, not the planning and designing of the content of the course.

The new discipline was understood in different ways at the four institutes of higher education, if the inaugural lectures are examined. The first argued for a Herbartian view on Pedagogik as an academic discipline (Hammer, 1910). His successor, Anderberg (1932), dealt with pedagogical aspects of studies of intelligence. The first lecture held in Lund was about the development of psychology into an exact science (Herrlin, 1912). His successor, Landquist (1936), talked of different ways of conducting psychological research. Landquist's successor, Siegvald (1947), compared the 
thinking of the child with the thinking of adults and polemicised against Piaget's conception of this difference. In Gothenburg, Jaederholm (1919) presented a 'chapter' from emotional psychology. This lecture was probably extemporised, so it is hard to know what it was about. Jaederholm's successor, Elmgren (1939), gave his inaugural lecture on the possibilities and limits of upbringing. In Stockholm, Katz (1937) began his talk on the most important researchers for his own development, Hering, Muller and Husserl, and continued by drawing a line between physiology and psychology and showing why psychological questions are not reducible to physiological issues. There is a closeness between the lectures held by Anderberg, Siegvald and Elmgren. The study of intelligence is a very important instrument for answering fundamental pedagogical questions for all of them. Add to this that Jaederholm introduced test psychology in Sweden in his doctoral thesis on the theory and practice of the measurement of intelligence (Lindberg \& Berge, 1988). Just looking at the lectures, first impressions are divided, but if you choose the professors working at the end of the period, three of them talked on subjects very close to intelligence testing and psychometrics, while the fourth took a more general psychological position. So far, this seems to be a sort of embryonic stage within Swedish Pedagogik. Now, this is a fragile conclusion. Four lectures within a period of fifteen years (1932-47)!

When checking the first professors' research publications after their inauguration, only three of them seem to remain with, and develop, the themes they had chosen for their inaugural lectures, viz. Anderberg, Siegvald and Elmgren (cf. Lindberg, 1999). In this study, the union catalogue of Swedish libraries (LIBRIS) was used and titles were compiled. It should be noted that Siegvald's doctoral thesis was the main scientific work, which qualified him for the professorship. Still, the conclusion from the inaugural lectures remains. Intelligence testing and psychometrics seems to be a core in these three professors' scholarly work.

In connection with an analysis of written expert reports on the assessment of applications for professorships of Pedagogik from 1910 to 1948, a series of lectures held by one professor in the 1920s was examined. The content of these lectures was not congruent with contemporary research by the professor or with his inaugural lecture. Later checks of the reports on the academic years from most of the period 1910-47 show that the content of education and teaching in the discipline hardly overlapped with the research conducted by the professors. This can be compared with Härnqvist's (1997) comment on the research-teaching relationship in the HSFR evaluation of educational research. After a short presentation of Pedagogik before 1948, he writes, 'The professor himself often had to spend much time lecturing and examining at an elementary level, far outside his research competence' (pp. 236-237). In the same article, Härnqvist writes that the scholar who was appointed to a professorship had to reduce his research activities, especially if the professor previously had been a research fellow with salary. 
When examining the documents from the appointments up to the middle of the century, there is a striking disagreement among the experts. In none of the appointments up to 1947 did the experts arrive at a joint recommendation about the future holder of the chair. What were the disagreements about? My reading of the experts' assessments of the applicants was concentrated on their judgements of the applicants' scholarly production (cf. Boyer, 1990). Three categories could be distinguished: the content of the research, the quantity of research activities and the quality of research. During this period the assessors focused on the content of research and whether this content reasonably could be characterised as Pedagogik. The experts, however, could not come to a unanimous agreement. The divergences are different and they are not exactly the same from competition to competition. For example, in one competition, two experts used between them 96 (52 plus 44) printed pages to give their views on the content of the professorship. However, one discussion was about the role of psychology in Pedagogik and consequently what weight qualifications in this area would have compared to other qualifications. Another discussion was about the content in all of them and the relations between the historical and philosophical parts, on one hand, and educational psychology and experimental Pedagogik on the other. These differences of opinion seem peculiar today, but the discussion in the Parliament and especially at the University of Lund (at the beginning of the century) focused in part on the possibility of Pedagogik being a scholarly activity. Some arguments, both in Lund (strong) and Uppsala (weak), were that psychology could give that legitimisation. The politicians in the Parliament, the schoolteachers' organisations and the National Board of Education wanted professorships in Pedagogik (Lindberg \& Lindberg, 1983, p. 3). As a sort of half compromise, these divergent opinions were interpreted in the direction that Pedagogik also was responsible for the discipline Psychology.

The most prominent unity during the period is the teacher education course that the professors had to teach. The syllabus was given and was the same during the whole of this period. Second, Pedagogik was responsible for psychology: towards the end of the period three of the four professors could be said to belong to an intelligence testing and psychometrical influenced current. Here there is a coherence between the contents in their inaugural lectures and important parts of their research activities. The conception of the discipline, however, was not unitary.

\section{Pedagogik 1950s-70}

Halfway through the century, the discipline was reorganised. Psychology acquired independent status as an academic discipline after having been the responsibility of the professors, albeit an indistinct responsibility. When this change took place, the chair holders were allowed to choose if they preferred the chair in psychology or Pedagogik och pedagogisk psykologi (educational 
psychology). All of them chose psychology and new professors were recruited to the chairs of Pedagogik. The main reason for the change seems to be the student influx. For example, the number of students per professor in 1905 was about 42 in Uppsala and about 11 in Stockholm. By 1945, the corresponding figures were 55 and 54 (Lindberg \& Berge, 1988, p. 92). The professors asked for a partition. Their arguments were twofold: the increasing teaching burden and the complicated nature of the discipline. So far, the professors were united. But there was no consensus on where to make the cut. One proposition was a professorship in psychology and psychological Pedagogik and one in Pedagogik oriented towards the history of Pedagogik. Another was a professorship in Pedagogik and one in psychology. A third was a professorship in psychology and Pedagogik with priority on general psychology and one in psychology and Pedagogik with priority on child, youth and industrial psychology. The university committee (SOU, 1946:81), which had to solve the problem, proposed one chair in psychology and one in Pedagogik och pedagogisk psykologi. The proposals from the professors reflected solutions suitable for themselves. Two of them got a solution that was in line with their interests. The other two chose the second best solution. In one way, all of them were oriented towards a psychology that was widely defined (Lindberg \& Berge, 1988, pp. 92-93).

Meanwhile, the reorganisation of the Swedish comprehensive school was at a critical juncture. An important governmental report was presented in 1948 and, as a consequence, a proposal for a new teacher education college was presented to the Government in 1952 (SOU, 1952:33). It should be noted that this organisation was not being thought of as part of the university organisation. The governing body was proposed to be the National Board of Education, which also was responsible for the compulsory and secondary school levels.

The main ideas associated with this proposal were that more time should be allocated for studies in Pedagogik and psychology, and that a 'community principle' should underpin 'real' teacher education. The meaning of this was that all teacher education students should be trained together irrespective of future teacher specialisation. Students should follow the experiments within the ongoing school reforms to stimulate their interest in pedagogical development work, and come up with valuable input to the reform work. To support the concentration on educational studies, a living contact with research seemed to be a necessity. Therefore it became important to establish research activities at the proposed college. It was said that this work should be directed by a scholar with distinguished qualifications comparable with the qualifications needed for a university chair. In the report it was also made clear that the main task for the professor in 'school research' was to take responsibility for the teaching in psychology and Pedagogik. The professorship could then, it was felt, be characterised as a research professorship. When this report was converted to a governmental policy proposal, the minister wrote about the content of the professorship: 
A certain specialisation would be desirable: it should give preference to research directed towards current issues in the school, while research directed towards history of education should withdraw. (Government proposal, 1954:209, p. 193; my translation)

The report stressed that there would be no risk of overlap with the activities at the departments at the universities. The experts on the committee underlined that the tasks in the renewal of the Swedish school would be many and that professors in both Pedagogik and psychology had a mission in this work within teacher education. The new professorships of school research were seen as a complement to the existing university chairs. It is evident that the experts in the governmental commission had the idea that these scholars, both at the universities and at the teacher education colleges, should be given responsibility to develop a knowledge base for school development and for teacher education within the frames of Pedagogik, psychology and the school research directions proposed for the professors at the teacher education colleges. Further, this knowledge base should be of a unitary kind. When Pedagogik was the object of a governmental commission in the late 1960s, the necessity of keeping the discipline together was discussed. It was argued that the different parts of the discipline were strongly interdependent, not least in the light of a system perspective, in which prerequisites, process and results are dependent on each other. One of the consequences of the commission work was that Pedagogik became the one and only denomination of the discipline (SOU, 1970:22)

When writing this article from a discipline perspective, the different commissions have to be commented upon. The report from 1952 is mainly a continuation of strong social demands for a much needed reorganisation of the Swedish parallel school system. For this reason, discipline interests did not count for much. Also, the professors at the university departments had got their preferred solutions. The report had taken into consideration a possible critique from the new (old) professors of psychology and from the future professors of Pedagogik and pedagogisk psykologi. More opportunities for these professors could be seen in the future. No fighting for resources was around the corner. All of these scholars could contribute to the change. The report from 1970 was mainly set up by scholars. The perspective was largely from within the discipline, and amongst other things, the consequences of the funding of school research during the 1960s. These two reports therefore reflect two different attitudes towards activities like research. The pragmatic one is the 1952 report, which can be said to be at best multidisciplinary, but it was not written by scholars. The latter report is one where the scholar perspective is strongly focused on what can be interpreted as the then ongoing discussion of a new denomination of the discipline Pedagogik.

New appointments took place both at the universities and at the teacher education colleges. Disagreements among the experts assessing the applicants' qualifications still occurred at the universities, although few in number. These disagreements were of the same kind as before and they were now expressed 
more sharply than before, questioning the necessity of a 'double' qualification for a professorship in Pedagogik. This double qualification can be summed up as follows: first (research) qualifications in psychology (particularly educational psychology) and second (research) qualifications in theoretical Pedagogik, comparative Pedagogik and history of education.

With respect to the assessors' reports on the appointments of professors between 1950 and 1975, there were four disagreements in a total of 22 cases. These four were in the early part of the period and were about the university professorships. Most of the new professorships were created at teacher education colleges and their qualification profiles were rather uniform. Looking at the arguments when placing one applicant before another, there is also a remarkable shift compared with the previous period. The experts concentrated on the quality of the scholarly (research) production. Only in the disagreements could discussions of the content of the discipline be observed. The quantity of the research production was mentioned, but practically always together with a comment on the relative insignificance of this type of criterion (Lindberg, 1987).

Research activities increased heavily, especially in the 1960s. In the middle of the 1970s more than 300 works were published every year (Lindberg \& Lindberg, 1983, p. 171). From 1948 to 1971 more than 1000 titles were published. A quantitative analysis of these titles indicates that educational research at least from the beginning of the 1960s was what, in the theory of scientific revolutions, is called a period of normal science: the number of scientific products increased substantially, dissertations were published within all problem areas, the production of each institution (department) was, with some exceptions, fairly homogeneous and, from a quantitative point of view, research about schooling dominated (Lindberg \& Lindberg, 1983, p. 54).

This impression of normal science could be illusionary. The chairs at each department at the universities and teacher education colleges in Sweden were asked to pick out 'model studies' from scholarly works published between 1948 and 1971. What they were to pick out were good studies, which were meant to serve as an example of what had been conducted in a special research field. The idea was to obtain material which reflected what researchers had been doing (Lindberg \& Lindberg, 1983, pp. 65-84). At the same time, 'model literature' was also picked out by the professors (pp. 85-99). The idea for doing this came from Kuhn's observation that in a science dominated by a particular paradigm, the fundamental scientific positions are expressed primarily in textbooks. Research begins where textbooks end. The analysis of these two sets of materials revealed a correspondence between the textbooks and the model studies. The predominant paradigm was neobehaviourism (p. 107). However, it was also possible to identify a hermeneutic approach within both model studies and textbooks. Even if the choice between poly- and multiparadigmatic phases was not unambiguous, the available arguments seemed to indicate a multiparadigmatic phase dominated by one specific paradigm but with indications of the presence of a second system of 
scientific norms and values (pp. 109-111). The model studies were also contextualised in the sense that they were analysed in relation to the purpose of each study and the financial conditions for each study. The conclusion of this analysis was that the existence of a predominant scientific paradigm probably constituted one of the main prerequisites of a massive concentration on educational research. However, external circumstances gradually changed and produced new research questions for the researchers within the discipline. The cadre of researchers was already there. The focus of educational research changed from a concentration on psychometric issues to a concentration on 'school research' (cf. Lindberg \& Lindblad, 2000). This new state of affairs suggests that the scientific ambition of educational research had gradually changed from descriptive and expository reports towards official reports on questions that were important for the authorities (cf. Lindberg \& Lindberg, 1983, p. 222).

During this period, psychology separated from Pedagogik. A new teacher education, disconnected from the universities but with professors in school research, and with the National Board of Education as the governing body, was launched. The content of the professorships were to be discussed when these belonged to the university organisation. The applicants for professorships within teacher education were to be discussed in connection with their scholarly qualifications. Research turned from psychometrics to school research, albeit within the same tradition, a neo-behaviouristic paradigm. Towards the end of the period, a unity definition of the discipline was formulated, the system approach.

\section{Pedagogik 1970s-2000}

From the descriptions from the two earlier periods, it should now be quite evident that the state governance of higher education has been very strong. However, during the last 25 years of the century there were general changes and, consequently, changes within the discipline and in the relationship of Pedagogik and teacher education. The first part of this section is a short review of general changes. The second part will focus on the general question posed by this article. As indicated in the introduction, this part is sketchy and tentative compared with the two other parts.

\section{General Changes in Higher Education}

Transitions in Swedish higher education were remarkable during this period. Mass education became a reality at university level. Syllabus decisions, previously decided by the Universities' Chancellor, were transferred to the universities, study programmes were created in humanities and social science, and teacher education became a part of the university system when most of the state-financed post-secondary education was brought together in a new, tertiary-level higher education. All these changes took place as a consequence 
of discussions in the 1960s and early 1970s around the construction of a university adjusted to the demands of social change. One of the more crucial aspects of these changes was that the responsibility for course content was transferred to the universities. The Degree Ordinance has always been strong in Sweden, and still is, but the tracks to a degree became more open. For example, the Ordinances for the training of secondary school teachers were almost intact from 1907 up to 1968, although the first teacher education colleges were launched in the middle of the 1950s. The period between 1977 and 1993 was one when the ties between the central authorities and the universities were gradually untied. The 1993 reform involved new relations between the state and the universities. The steering system changed to management by objectives. The Degree Order was also changed. Three types of degrees now regulated teaching activities within higher education:

general (master, bachelor and diplomas) for undergraduate students; professional degrees (e.g. University Diploma in Architecture, University Diploma in Education for Upper Secondary School, University Diploma in Education for Primary and Secondary School) for undergraduate students; doctorates or licentiate degrees for postgraduate students.

The main content is stipulated for professional degrees. For other degrees (both undergraduate and postgraduate) there is a regulatory system for the course of studies which must be followed before students can be awarded their degrees. However, it is up to the university teachers within these frames to shape the content of the courses. Within these degrees the disciplinary influence can be strong, provided that undergraduate and doctoral students attend the offered courses. The Ministry of Education allocates the universities student places within different faculties. A sum of money follows for each student and the universities have to examine all the students they are assigned to get this payment. Admission to postgraduate studies is determined by the possibility of financing the salaries of doctoral and licentiate students. The faculties are not allowed to admit a student to a doctoral programme until the funding for four-year full-time studies can be guaranteed. A small and decreasing amount of money can be used for research activities from the payments for undergraduate and postgraduate teaching. The greater part of research activities are today financed by grants from research councils, authorities and agencies. The quality of teaching activities is assessed by the National Agency for Higher Education. The quality of research is assessed by research councils or by a government commission. The main idea behind these assessments is peer review.

\section{Pedagogik}

As indicated in the introduction, research during this period has changed. Comparing Lindberg \& Lindberg (1983) with the HSFR evaluation (Rosengren $\&$ Öhngren, 1997) shows a smooth but also a dramatic change in research 
perspectives and approaches. Lindberg \& Lindberg (1983) used Kuhn's theory as a theoretical tool in their analysis, and if the same approach is used on the HSFR evaluation, it is reasonable to characterise the shift as from a mainly neo-behaviouristic paradigm with a main focus on school research in the late 1960 s to a multiparadigmatic state in the 1990s with quite a lot of different foci.

Let us move to another source. Descriptions of the discipline 'Pedagogik' in the syllabuses have been collected every fifth year between the mid-1970s and 2000 from every department of Pedagogik in Sweden. It is customary to find a description of this kind in every single syllabus within a discipline. When looking at syllabuses within a study programme for a professional degree, descriptions of this kind are not a matter of course. My impression from the reading of these is that departments of 'Pedagogik' have been rethinking and reworking their descriptions. The changes are not dramatic, but the descriptions change. There are differences between the departments, but these are not so divergent that they can be said to be contradictory. The usual descriptions state that 'Pedagogik' is a discipline which deals with issues of upbringing, education and teaching and sometimes other influences which aim at realising societal and individual goals. This general study object is placed in a context of values, culture and the society in question. This provides room for both historical and comparative approaches. So far, it is easy to conclude that there is still a connection with what was outlined in the first inaugural lecture held in Sweden. However, the Herbartian focus in the first lecture should not be stressed too much. Changes in the descriptions have been introduced during the last decade: the most usual one is that learning, widely defined, has a place in the descriptions at some departments and that communication, influences (societal) and socialisation do in other departments. These changes open up the way for interdisciplinary approaches. However, this is just a first analysis of this material. The next will be about the course content and course literature with a focus on what is said about the discipline Pedagogik.

The tensions between the discipline and the professional preparation of teachers are a main theme through the century. Looking back on the closeness between state interest and the discipline, it seems that there are two sides of the coin: one is about input to the discipline (research funds) and the other is the delivery side. The first is supplied with possibilities on conducting research; the other weakened the disciplinary identity (cf. the 1960s). Still, state intervention has been based on a confidence in what the discipline (or almost the discipline) could deliver. This confidence now seems to be shaken. The Swedish Government in 1997 appointed a parliamentary committee to come up with proposals for a renewal of teacher education. The committee proposed amongst other things a research strategy for teacher education and pedagogical work (SOU, 1999:63). After circulation of this report, the Government, in spring 2000, presented a proposal to the parliament on guidelines and prerequisites for the renewal of teacher education. The proposal was largely accepted. The parliamentarians in the committee argued for a strengthening of a professional identity for teachers. They said that a 
decentralised and goal-directed pedagogical trade produces new demands on employees. To answer to these demands and to be able to plan and develop their teaching work, teachers need a deeper power of theoretical reflection over teaching activities, deeper knowledge within different subjects and knowledge areas, good knowledge about and contact with research, and to develop a more secure professional identity. To handle these changed tasks, the committee proposed that a well-developed and diversified research milieu in good contact with the activities in school was a necessity. To carry this out, they maintained that research activities have to be adjusted to the school context and that the universities and the municipalities should get closer to each other in order to give teachers increased opportunities to do research within and on the school. In this context, teacher education, according to the parliamentarians, will have a dual task: to prepare the student teachers in work-related research and to act as a link between developmental work in school and ongoing research at universities and colleges.

The research strategy will strengthen the professional identity among the employees in school. The strategy is intended, for example, to develop a common knowledge base, common ethical principles and a joint professional language.

According to the parliamentarians, there may be other paths to doctoral studies than within the already established ones in connection with the discipline 'Pedagogik'. One example is an interdisciplinary research development. They presented other possibilities for research in connection with school subjects and/or academic disciplines and new disciplines such as pedagogical work, knowledge production and learning and special education. They underlined the connections between interdisciplinary research areas and the academic disciplines involved in teacher education. They also pointed to didactics (both subject and general) as another basis for doctoral studies. All disciplines involved in undergraduate teacher education will also carry out research and postgraduate teaching. The parliamentarians suggested that a new faculty should be established, viz. sciences of education. They compared this proposal for a new faculty with the existing faculties of medicine, technology and other faculties with direct focus on vocational training through a connection to and a foundation on a university placed professional education.

When the parliamentarians wrote about Pedagogik, they did so negatively. One conclusion drawn was that teacher education has no research base of its own, and a tacit assumption was that Pedagogik had not created this base. The committee did not think that Pedagogik had ended up as an applied science compared with, for example, social work and the study programme for social workers. They compared the situation with the Faculty of Medicine and concluded that what is missing for teacher education is the equivalent of clinical research disciplines. They maintained that the departments of Pedagogik had not widened the research base for teacher education or successfully produced enough doctors to fill the positions within teacher 
education. A more indirect critique was that the greater part of the teacher education students were prevented from advancing to doctoral studies after the completion of their undergraduate studies. When the parliamentarians proposed a new science area, 'sciences of education', they also stated that this should contribute to making clear the role of the departments of 'Pedagogik' in relation to teacher education, on the one hand, and social science, on the other.

During this period, there is a distinct shift in research perspectives and approaches. The conceptions of the discipline, as these can be understood from the syllabuses, from the mid-1970s up to the millennium, seem to be stable; however, there are minor shifts at the end of the period. Learning and communication are concepts which are brought into the definitions in some departments. At the end of the period, members of parliament seem to be searching for another knowledge base for teacher education than Pedagogik.

\section{Concluding Remarks}

In one way, it is too early to discuss answers to the question whether Pedagogik is just a phenomenon of the twentieth century. Further analysis of collected material (e.g. written expert reports, course literature) and material under collection (e. g. inaugural lectures, decisions in the new Swedish Science Council) will probably give valuable input. However, some tentative remarks can be made.

When comparing the governmental reports (SOU, 1952:33 and SOU, 1999:63), the resemblance in the first place is striking. The second report can be taken for a blueprint: the research should be close to work and practical; teacher education should be the power in the development of school activities. However, a closer reading shows important differences. The common knowledge base in the early report implies for the most part 'Pedagogik' as the research area for teacher education. In the second report, the common knowledge base has a different content. It should be interdisciplinary and the greater part of all disciplines within the faculties of social science, humanities and natural sciences engaged in teacher education should also be a part of this 'common' knowledge base. Common has got a new meaning here; unity is exchanged for fragmentation.

It is tempting to conclude that Pedagogik during the 1960s and 1970s was a 'container' for state interventions in the school sector, especially with respect to research. The transitions of research foci and approaches during the 1990s change these into what can be called a multiparadigmatic state. On the other hand, it seems that there is a disciplinary unity within teaching activities on all levels which indicates that the step into the category sciences of education has not (yet?) been taken.

There are still questions which have to be answered. Why does it seem impossible for Pedagogik to be a knowledge base for teacher education? Most of the activities that were asked for had already been there for years. Why is it 
Leif Lindberg

possible for Pedagogik to contribute to other professional study programmes, such as postgraduate psychology and human resources management and development, without the tensions demonstrated in connection with teacher education? Why are the relations between researchers in Pedagogik and teachers in school normally very good?

A point of view for further analysis is to place a line between Pedagogik as an intellectual activity and other activities that are usual in an academic field, such as organisational struggles for power, control and resources. Sorting what is going on within and around the discipline in that way may contribute to a better understanding of the ongoing transitions.

\section{Acknowledgement}

This article is written within a project with the same title. The project is financed by a grant from the Swedish Research Council. My thanks to Joakim Lindgren, BA, for his help preparing material used in this article, to Dr Ingeborg Moqvist and Dr Christina Segerholm for valuable comments on the paper version of the manuscript, and to Dr Rita Hofstetter and Dr Bernard Schneuwly for constructive comments on a first draft of the manuscript.

\section{Note}

[1] The Swedish term 'Pedagogik' is used throughout this article since it seems to be hard to find a term in English which is equivalent. Neither 'education' in English nor 'éducation' in French has the same meaning. Even for the authors of the Swedish dictionary for the educational area the task of finding an equivalent term was too much.

\section{References}

Ahlström, K-G. \&Magnusson, D. (1997) Pedagogik. I magisterexamen söker sin identitet [The master degree looks for its identity]. Högskoleverkets rapportserie, p. 45. R. Stockholm: Högskoleverket. / Pedagogik (in Swedish).

Boethio, D. (1788-1792) Primae Scientiae Educationis Lineae. Particulam I-Particulam XIX. Uppsaliae: Litteris Joh. Edman (in Latin).

Boyer, E.L. (1990) Scholarship Reconsidered. Priorities of the Professoriate. Carnegie Foundation for the Advancement of Teaching. Princeton: Princeton University Press.

Geiger, R.L. (1975) The Institutionalization of Sociological Paradigms: three examples from early French sociology, Journal of the History of the Behavioral Sciences, 11, pp. 235-245.

Governmental proposal 1954:209.

Härnqvist, K. (1997) Educational Research in Sweden: infrastructure and orientation, in K.E. Rosengren \& B. Öhngren (Eds) An Evaluation of Swedish Research in 
Education, pp. 235-272. Uppsala: Swedish Council for Research in the Humanities and Social Sciences.

Hofstetter, R. \& Schneuwly, B. (2001) Educational Science in Switzerland. Evolution and Outlooks. Centre for Science and Technology Studies, CEST 2001 / 6.

Karnung, G. (2001) Röster om kvalitativ forskning. En karaktäristik utifrån vetenskapliga texter [Voices about qualitative research: some characteristics based on scientific texts]. Acta Universitatis Upsaliensis [Uppsala Studies in Education 97]. Uppsala (in Swedish with a summary in English).

Lindberg, L. (1987) Om utvärdering av forskning. Några anmärkningar med utgångspunkt i sakkunnigutlåtanden vid professorstillsättningar i pedagogik 1910-1985 [On assessment of research activities - some remarks based on written experts' assessments of applicants for professorships of 'pedagogik' 1910-1985], in H. Andersson, L. Akademi \& L. Lindberg Pedagogik och historiaPedagogik och historia (Dokumentation från Pedagogiska fakulteten, Åbo nr 30) (in Swedish).

Lindberg, L. (1992) Symbolhandlingar och pedagogik som vetenskaplig discipline [Symbol acts and 'pedagogik' as social science], Forskning om utbildning 2, pp. 27-47 (in Swedish, with an abstract in English).

Lindberg, L. (1999) Research Publications: Swedish professors of Pedagogik (from Hammer to Siegvald) according to LIBRIS 1999-11-09.

Lindberg, L. (2000a) Pedagogiken som vetenskap i svenskt perspektivPedagogiken ['Pedagogik' as social science, a Swedish perspective], in M. Uljens (Ed.) Pedagogikens problem. Kulturella utvecklingslinjer och teoretiska spörsmål. (Studier i pedagogikens teori och filosofi, nr 12). Pedagogiska institutionen Åbo Akademi, Vasa Finland. pp. 47-56 (in Swedish).

Lindberg, L. (2000b) The Swedish Academic Recruitment System in Transition. Unpublished manuscript, Umeå University, Department of Education.

Lindberg, L. \& Berge, B-M (1988) Pedagogik som vetenskap-vetenskap som pedagogic ['Pedagogik' as social science - social science as pedagogy]. Lund: Studentlitteratur (in German [in part] and Swedish).

Lindberg, G. \& Lindberg, L. (1983) Pedagogisk forskning i Sverige 1948-71. En explorativ studie av utom- och inomvetenskapliga faktorer [Educational research in Sweden 1948-71. An explorative study of internal and external factors], doctoral dissertation at the Faculty of Social Sciences, University of Umeå (in Swedish with a summary in English).

Lindberg, L. \& Lindblad, S. (2000) European Geography of Educational Research: the case of Sweden, paper presented at the European Conference on Educational Research, Edinburgh, 20-23 September.

Rosengren, K.E. \& Öhngren, B. (Eds) (1997) An Evaluation of Swedish Research in Education. Uppsala: Swedish Council for Research in the Humanities and Social Sciences.

SOU 1922:17. Betänkande och förslag rörande det akademiska befordringsväsendet [Commission report and proposals regarding the academic recruitment system] (in Swedish).

SOU 1946:81. 1945 års universitetsberedning II. Akademiska lärarbefattningar samt anslag till den vetenskapliga utbildningen $\mathrm{mm}$ [Commission on universities II. Academic teaching posts and allocations for academic teaching etc.] 
Leif Lindberg

SOU 1952:33. Den första lärarhögskolan. Stockholm: Ecklesiastikdepartementet [The first Teacher Education College] (in Swedish).

SOU 1970:22. Pedagogisk utbildning och forskning [Educational research and pedagogical education]. Stockholm: Utbildningsdepartementet (in Swedish).

SOU 1999:63. Att lära och leda [To learn and to direct]. Stockholm:

Utbildningsdepartementet (in Swedish).

LEIF LINDBERG is an associate professor at the Department of Education, Växjö University, Sweden and Director of the University Centre for Educational Development. Previously, he had taken his $\mathrm{PhD}$ and became a Docent in the Faculty of Social Sciences, Umeå University, Sweden. His research interests include the history and sociology of social sciences, higher education, evaluation studies, equity studies in higher education, and academic leadership. Correspondence: Leif Lindberg, University Centre for Educational Development, Växjö University, SE-351 95, Växjö, Sweden (leif.lindberg@adm.vxu.se). 